\title{
Changes of flood risk on the northern foothills of the Tatra Mountains
}

\author{
Z. W. Kundzewicz ${ }^{1}$ M. Stoffel ${ }^{2,3} \cdot$ B. Wyżga ${ }^{4,5} \cdot$ V. Ruiz-Villanueva ${ }^{2,3} \cdot$ \\ T. Niedźwiedź ${ }^{5}$ R. Kaczka ${ }^{5}$ J. A. Ballesteros-Cánovas ${ }^{2,3}$ - I. Pińskwar ${ }^{1}$. \\ E. Lupikasza ${ }^{5}$ J. Zawiejska ${ }^{6} \cdot$ P. Mikuś $^{4} \cdot$ A. Choryński ${ }^{1} \cdot$ H. Hajdukiewicz ${ }^{4}$. \\ B. Spyt $^{5} \cdot$ K. Janecka ${ }^{5}$
}

Received: 3 March 2017/ Accepted: 12 August 2017/Published online: 24 August 2017

(c) The Author(s) 2017. This article is an open access publication

\begin{abstract}
The present paper reviews selected outcomes of the FLORIST project devoted to flood risk in the region of the northern foothills of the Tatra Mountains in Poland and summarizes novel results. The project encompassed theoretical, field, and modeling work. It was focused around observation-based hydroclimatology; projections for the future; dendrogeomorphology; as well as influence of transport of large wood on fluvial processes. The project improved understanding and interpreting changes in highflow frequency and magnitude as well as changes in flood risk in the region, related to the presence of large wood in mountain streams. A unique database on past episodes of intense precipitation and flooding was created, harnessing multiple sources. The project showed that the analysis of tree rings and wood logs can offer useful information, complementing and considerably enriching the knowledge of river floods in the region of northern foothills of the Tatra Mountains. Retrospective and scenario-defined
\end{abstract}

Z. W. Kundzewicz

kundzewicz@yahoo.com

1 Institute for Agricultural and Forest Environment, Polish Academy of Sciences, Poznań, Poland

2 Dendrolab.ch, Institute of Geological Sciences, University of Bern, Bern, Switzerland

3 Climatic Change and Climate Impacts, Institute for Environmental Sciences, University of Geneva, Geneva, Switzerland

4 Institute of Nature Conservation, Polish Academy of Sciences, Kraków, Poland

5 Faculty of Earth Sciences, University of Silesia, Katowice, Poland

6 Institute of Geography, Pedagogical University of Cracow, Kraków, Poland modeling of selected past fluvial events in the region was also performed.

Keywords Flood risk · Flood hazard · Upper Vistula Basin · Poland

\section{Introduction}

In recent decades, flood losses have considerably grown at every spatial scale, from local to regional, national, continental, and global (Kundzewicz et al. 2013, 2014a). In two recent decades, there were 2 years (1997 and 2010) when economic losses caused by floods in Poland soared to the level of $1 \%$ of the national GDP and the number of fatalities reached several dozens (Kundzewicz et al. 2012). In the area of the Tatra Mountains and their foothills, annual precipitation is higher than anywhere else in Poland. In the Tatra Mountains, precipitation is by $50-100 \%$ higher than in the remaining parts of the Polish Carpathians and 2-3 times higher than in the lowland part of Poland. Heavy rains can lead to generation of river floods that propagate northwards over hundreds of kilometers, down to the lowland areas. Hence, the Polish-Swiss research project "Flood risk on the northern foothills of the Tatra Mountains" (FLORIST), carried out from July 2011 to September 2016, was of considerable social relevance, as well as of theoretical and practical importance and interest.

\section{Research objectives}

Among the primary objectives of the FLORIST project (Kundzewicz et al. 2014b) were the following: 
- Creating an information database on torrential disasters and floods in the region, including magnitude and frequency, flood-producing mechanisms, triggers, and impacts. Several sources were harnessed: from routine observations made by the hydrometeorological service, to references, and to innovative dendrogeomorphology contribution generated within the FLORIST project.

- Estimating flood risk changes resulting from in-channel wood. One of the relevant activities was a series of tracking experiments, where metal tags and radio transmitters were used, fixed to trees growing along channel banks and to logs put into the river. Patterns of wood storage in mountain streams were examined, dependent on the ratio of stream width and riparian tree height. Mathematical modeling of transport and retention of large wood was also carried out, as well as analysis of probability of bridge clogging with inchannel wood.

- Performing detection of change in long-time series of intense precipitation observation records, as well as atmospheric circulation patterns and high river flows.

- Analyzing projections of future changes in the frequency and magnitude of intense precipitation and high stream-flow. This included comparison of the situation in two time intervals-in the reference period and in the future projection horizon.

- Performing mathematical modeling (both retrospective and scenario-defined) of selected torrential disaster events and river floods as well as assessing involved risks, linking climatic variables with characteristics of torrential disasters and river floods for the reference period and modeling of selected past events.

The present paper reviews selected outcomes of the FLORIST project and presents novel results.

\section{Data and methods}

Meteorological and hydrological data used in the FLORIST project were provided by the IMGW-PIB (Institute of Meteorology and Water Management-National Research Institute, being Polish National Hydrometeorological Service). Field work undertaken within the FLORIST project, particularly related to flood scars on trees, dendrochronology, and wood transport and deposition, generated additional data.

The project embraced three essential areas that can be labelled as: theory and field work, as well as mathematical modeling. There were four competence clusters in the project, focused around:

1. climatology and hydrology based on observations;

2. projections of future climate change and its impact;
3. dendrogeomorphology; and

4. influence of large wood on geomorphological processes.

\section{Climatology and hydrology}

The information database was constructed in the FLORIST project, allowing to provide reconstruction and interpretation of characteristics of past flood disasters. Use was made of hydrometeorological records stemming from the IMGW-PIB operational network and from the OGIMET synoptic data base, as well as of own data, collected in the FLORIST project. The collection of the meteorological data was undertaken as well as the calendar of atmospheric circulation types, air mass, and atmospheric fronts was produced. A hydrological database of flow of rivers and streams, as well as of floods in the area of study, and a collection of historical information for the area were created.

The FLORIST project included examination of variability of climatic and hydrological processes in the area of study. Changes in meteorological conditions and heavy precipitation in particular (Łupikasza et al. 2016), as well as changes in atmospheric circulation patterns enhancing the likelihood of heavy precipitation, floods and torrential disasters (Niedźwiedź et al. 2015; Niedźwiedź and Łupikasza 2016), and changes in observed stream-flow records, were examined. Links between the circulation patterns and dated flood events were analyzed. A few circulation indices, such as cyclonicity index and circulation indices (meridional—southerly and zonal—westerly), were examined and compared with the NAO index value, as well as correlated with heavy precipitation. Analysis of recent changes in magnitude, frequency, and seasonality of floods was also carried out.

River flow data from 14 gauging stations located in the study region, characterizing catchments with an area between 34.5 and $4341 \mathrm{~km}^{2}$, were analyzed (Ruiz-Villanueva et al. 2016a, c). Stations were selected for the analysis of possible changes in river flow depending on the accessibility of network data, lack of considerable impacts from water management activities (e.g. impoundment), spatial independence between gauging stations, and availability of at least 30 years of uninterrupted and complete observation records.

Detection of change was carried in long observation records of annual and seasonal maximum discharges, as well as peak-over-threshold magnitude and frequency with the help of the nonparametric Mann-Kendall (MK) test. A multi-temporal approach was employed in which trends were determined for every possible combination of the first and last year in a given record. A pixel in the plot of multi- 
temporal trend represented a fixed study period (the traditional approach).

Next, potential drivers for attribution were sought for the explanation and interpretation of the detected changes, with the help of correlating the analyzed flood parameters with a range of large-scale climate indices, indices of intense precipitation, duration of snow cover, and types of cyclonic circulation. Catchment alterations and changes in stream-channel morphology that occurred in study area since 1950 s were also analyzed.

The climate track in the project included studying observations as well as projections for the future. A set of the state-of-the-art climate model results, available from the EU CORDEX project, were applied to represent future conditions. Based on spatially downscaled climate model ensemble projections, we examined the likelihood of occurrence of changes in frequency and magnitude of intense precipitation, as well as high flow in various future time horizons. Projections of future flood hazard changes were also analyzed.

\section{Flood information derived from trees and wood}

Important and innovative information related to floods was derived from trees (dendrochronology) as well as woodits entrainment, transport, and deposition. A collection of tree-ring samples was assembled, with particular attention paid to flood scars and traumatic resin ducts that resulted from the impacts of wood debris carried in floodwaters (Fig. 1). The riparian trees in four selected mountain

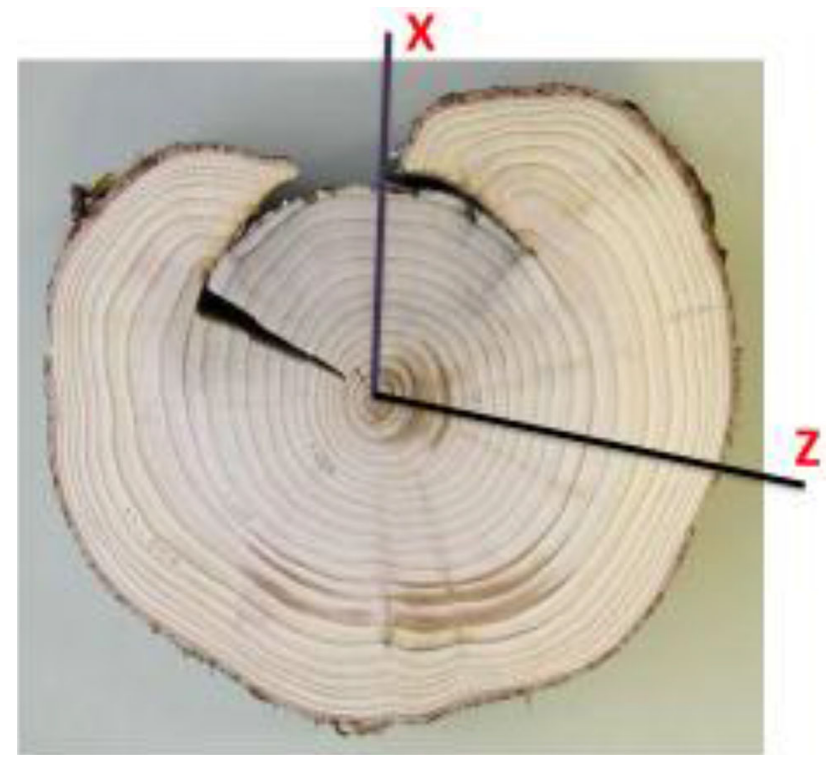

Fig. 1 Dating floods based on the position of scars and resin ducts in the wood. Event scale may be reconstructed from the vertical position and scar sizes. Note: $X$ core taken from the wound; $Z$ core from undisturbed part of a trunk stream catchments were sampled ( $\sim 50$ sampled trees per site) using increment borer. The samples were subjected to dendrogeomorphological analysis, including recognizing the scars and traumatic resin ducts under a binocular, crossdating against reference chronology. As a result, the information about years of flood occurrence were derived.

Dendrochronological research in the Tatra Mountains and their foreland (Fig. 2) provided data for reconstruction of the parameters of flood events and of the regional climate characteristics. The results were used to reconstruct chronologies of major floods that had occurred in headwater catchments. A database with detailed information on each sample was constructed using results for individual trees. To date the past flood events in Tatra streams and reconstruct their peak discharges, dendrogeomorphological procedures were developed. Core samples of conifers, such as Norway spruce, stone pine, and Scots pine (respectively, Picea abies, Pinus cembra, and Pinus sylvestris), were examined to infer and reconstruct air temperatures and humidity (Kaczka et al. 2016).

Apart from dendrochronological analyses, tracking experiments using tagged wood were carried out in an attempt to quantify in-channel wood transport and provide data on the potential for the large wood retention of instream sections with differing morphologies, and management of stream channel and their neighborhood. In these experiments, trees growing along river banks threatened by erosion and logs put into a river during flood conditions were equipped with either metal tags or radio transmitters.

We monitored recruitment of large wood, as well as its transport and retention in watercourses of different size in the study area over the duration of the project. Rich wood inventory in Kamienica stream was combined with a comprehensive analysis of conditions that promote transport or storage of wood in the small mountain stream. The monitoring of trees and wood logs tagged with metal plates

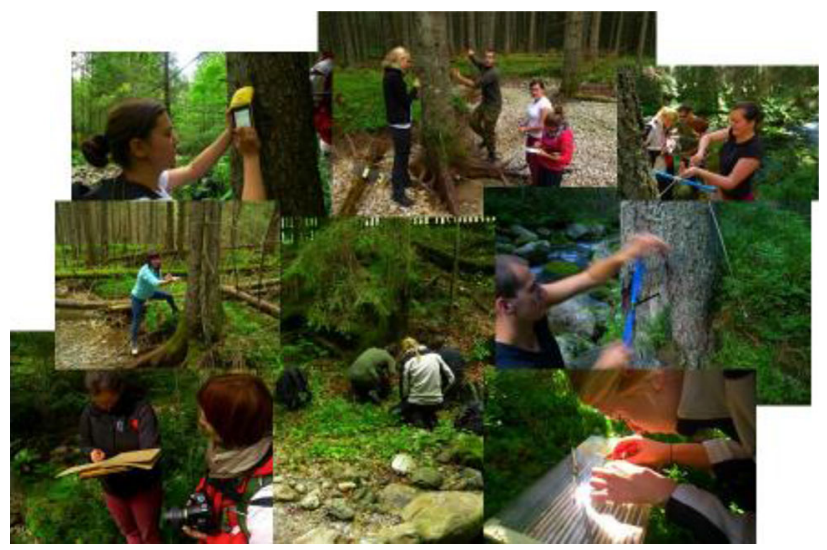

Fig. 2 Dendrochronological fieldwork focused on obtaining information about past climate and floods 
along the stream was conducted, accompanied by detailed geomorphological mapping, including the inventory of instream wood. Log transport and deposition during high flow in a mountainous river were also investigated in the River Czarny Dunajec.

Surveying of thousands of wood accumulations in many dozens of channel segments allowed us to relate characteristics of wood to morphometric stream-channel parameters. We performed monitoring of the flood movement via tagged logs (with radio transmitters) in the River Czarny Dunajec during a medium-size spring flood of approximately 20-year recurrence interval (Wyżga et al. 2016b). Situation of installed radio transmitters was repeatedly monitored. To perform numerical modeling of transport and deposition of large wood in the River Czarny Dunajec, data related to the size of river-bed material, spatial pattern of main channel features, as well as land cover in the riparian area were collected.

Field studies on the transport of wood in the River Czarny Dunajec, carried out within the FLORIST project, were complemented with a hydrodynamic wood transport modeling, aimed at improvement of the knowledge of interactions between large wood, and channel and floodplain boundary. In these studies, a synergistic effect was obtained by combination of direct-field observation records and numerical (probabilistic) modeling. Among the many investigated aspects were: (1) large wood transport; (2) large wood deposition; (3) impacts of flood hydrograph (its shape and magnitude) on the dynamics of large wood; and (4) large wood remobilization by sequencing floods. The model originally developed by a FLORIST project scientist was used to run several scenarios, pertaining to a roster of hydrodynamics and wood transport regimes. The solution of the 2D hydrodynamic flow model was achieved with the help of finite volume method, incorporating a Lagrangian module. The position and velocity of wood logs were calculated, based on the balance of forces involved in flow conditions and wood motion. Calibration and validation of the model were based on field-derived observations, and data such as discharge and rating curve from the nearest stream gauging station, measurements of bed material size, and land-use data. Simulations gave valuable insight into the dynamics of wood transport related to several issues, such as discharge thresholds for wood transport, as well as the relationships between discharge and wood transport rates (Ruiz-Villanueva et al. 2016f), and relations between bed elevation, geomorphic features, and wood deposits. Also relations between channel and floodplain roughness, and wood deposits, distance travelled, as well as antecedent flood effect (Ruiz-Villanueva et al. 2016b), the role of flood hydrograph on mobility of large wood (Ruiz-Villanueva et al. 2016d), and the potential bridges clogging (Ruiz-Villanueva et al. 2016h) were examined.
An environment-friendly approach for the reduction of flood risk and damage to infrastructure was applied to a mountain river reach (Mikuś et al. 2016b).

The prime examples of major methodological innovations in the FLORIST project were:

- generation of unique database on past episodes of heavy precipitation and flooding, based on various sources, such as flood scar analysis in living trees and dendrochronology;

- analysis of changes in heavy precipitation, atmospheric circulation patterns, and high river flows;

- assessment of flood risk resulting from the transport and deposition of in-channel wood, including innovative ideas of field experiment as well as modeling of transport of wood and determination of the probability of bridge clogging;

- analysis of projections of future climate, using state-ofthe-art modeling results.

\section{Major results}

The present paper reviews outcomes of the FLORIST project and presents some novel results. It also refers to journal articles listed in references, as well as to the book "Flood Risk in the Upper Vistula Basin" (Kundzewicz et al. 2016). This important monograph, covering the whole Upper Vistula Basin rather than just the foothills of the Tatra Mountains, gives comprehensive account of the results of the FLORIST project. The book attracted voluntary participation of excellent experts also from beyond the FLORIST project. The book offered material on management of flood risk and climate change adaptation, vigorously supported by highly competent scientists external to the project. Wyżga et al. (2016c) juxtaposed traditional vs alternative measures of flood risk management in the Upper Vistula Basin. Matczak et al. (2016) examined strategies of governance of flood risk in Poland, with particular focus on stability and change, while Konieczny et al. (2016) discussed opportunities for learning, being yet another dimension of flood risk reduction. Nachlik and Kundzewicz (2016) summarized the chronology of large flood events on the Upper Vistula River.

The FLORIST project enlarged available information related to floods in mountainous basins (Stoffel et al. 2016a, b) as well as discussion of the anatomy of flood risk (Kundzewicz and Stoffel 2016). A roster of mechanisms of flood generation were reviewed, as well as changes in principal drivers influencing flood risk and flood hazard (Wyżga et al. 2016a).

The FLORIST project extended the available knowledge related to generating processes, and driving flood hazard 
and flood risk, in the area of study. Information on past disasters was acquired from various sources, including routine operational observation networks, scientific publications, as well as original field studies undertaken within the FLORIST project.

Changes in observation records in the region were deciphered, such as temperature and precipitation changes, and relationships between them (Łupikasza et al. 2016). Changes in atmospheric circulation patterns favoring heavy precipitation were detected by Niedźwiedź and Łupikasza (2016). Even if most changes were found to be insignificant, they reported some statistically significant increases in the frequency of atmospheric circulation types. RuizVillanueva et al. (2016a, c) deciphered changes in the observed variability of high stream-flow (its frequency and magnitude) in the study area. They noted strong interdecadal variability as well as shifts in seasonality, namely decreases in magnitude of winter high flow as well as increases in autumn and spring. The project contributed to the improvement of understanding and reduced uncertainty in the interpretation of observed change in the frequency and magnitude of heavy precipitation and flood discharges in mountainous catchments. However, in general, the hitherto existing evidence is conflicting. No consistent and ubiquitous finding was made of major floods getting significantly more intense and more frequent.

The FLORIST project also analyzed climate change projections. Pińskwar et al. (2016) reviewed projections of future precipitation in the study area. Climate models predict a likely increase in frequency, severity, and duration of intense precipitation (Pińskwar et al. 2016), and this may translate into increase of the climate-relevant component of future flood risk. River discharge projections covering the whole Upper Vistula Basin and projections of flood hazard changes in two headwater catchments were presented by, respectively, Piniewski et al. (2016) as well as Romanowicz et al. (2016). In the former study, an increase in future high river flows was found, while projections of changes in flood hazard reported in the latter study were less consistent. They were shown to depend on the climate model, the projection horizon (2020s, 2050s, 2080s), as well as the site. In brief, the findings presented in the work by Romanowicz et al. (2016) were loaded with considerable uncertainty. Indeed, one can generally state that changes in torrential activity are complex and may exhibit different patterns that depend on the used model and the region of study, so that generalized conclusions are not possible. This is in line with the findings on uncertainty in flood hazard projections reported in Kundzewicz et al. (2010, 2017). Krasovskaia et al. (1999) illustrate aspects of complexity.

The reconstruction of climate including the summer temperature and precipitation for last 380 and 309 years, respectively (Fig. 3), created the comprehensive background for the analyses of recent climate factors responsible for flood occurrence (Kaczka et al. 2016).

Field experiments dealing with dendrogeomorphology and flood scars, undertaken in the FLORIST project, aimed at enhancing the interpretation and understanding of flood risk in the study area. Ballesteros-Cánovas et al. (2015, 2016a, b) deciphered novel information about the timing and magnitude of floods in four ungauged mountain watercourses located in Western and High Tatras from flood scar observations and tree-ring data (Fig. 4).

The dynamics of large wood transport as well as its impact on flood hazard in the study area-the Stream Kamienica and the River Czarny Dunajec-were assessed by Mikuś et al. (2016a). Figure 5 presents an example of information derived from large wood inventory in the Kamienica, which was used to infer about wood mobility in the stream. A considerable increase in the proportion of wood pieces at advanced stage of decay over 15 years after the large flood of 1997 evidences insignificant mobility of wood pieces that were recruited to the stream, especially its second-order reach, during the flood. Results of numerical modeling of large wood transport, deposition, as well as remobilization during floods in contrasting morphologies of mountain rivers were reviewed by Ruiz-Villanueva et al. (2016g). Hydraulic conditions of flood propagation in a stream that was subjected to spatially variable anthropogenic pressures were discussed by Radecki-Pawlik et al. (2016). The project improved recognition of the risk resulting from the interaction between high discharge and large wood occurring in mountain streams. Wyżga et al. (2015) compared observation records assembled in wood inventories associated with streams, whose ratio of channel width to the height of trees growing in their riparian areas was largely different (i.e. being narrower or wider), and examined patterns of wood storage in these watercourses. They found that different effects on the flood risk can be observed, related to either the floated debris or to flow obstructions in both types of watercourses (Figs. 6, 7).

Outcomes from the numerical modeling of wood behavior in the River Czarny Dunajec allowed to determine the main factors governing transport and deposition of wood (respectively, Ruiz-Villanueva et al. 2016b, f). Setting different scenarios allowed the authors to find relationships between geomorphic configuration of the mountain river and wood deposits, flood magnitude and wood transport rates (defining mobility thresholds), etc. These relationships were examined for two types of river reaches: a narrow, partially channelized, single-thread reach and a wider, multi-thread, channel reach. In result, information on dynamics and deposition of large wood was gathered, so that understanding of the interactions between large wood and river corridor was improved. The modeling 


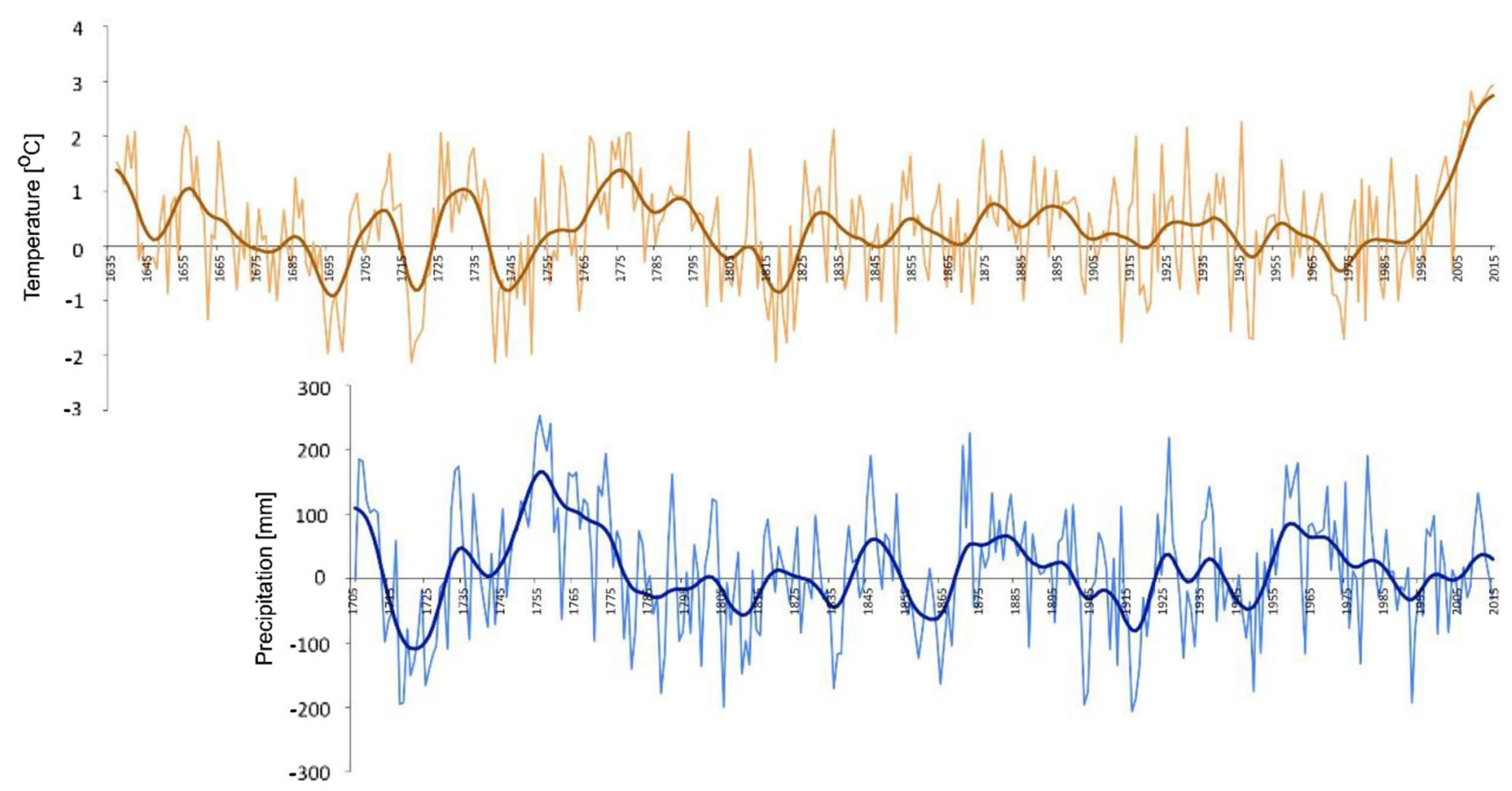

Fig. 3 Climate reconstruction of the Tatra Mountains Region, over the period 1636-2015 for June-July temperature and 1705-2013 for JuneJuly precipitation. The temperature values represent anomalies $\left({ }^{\circ} \mathrm{C}\right)$ from the $1961-1990$ mean

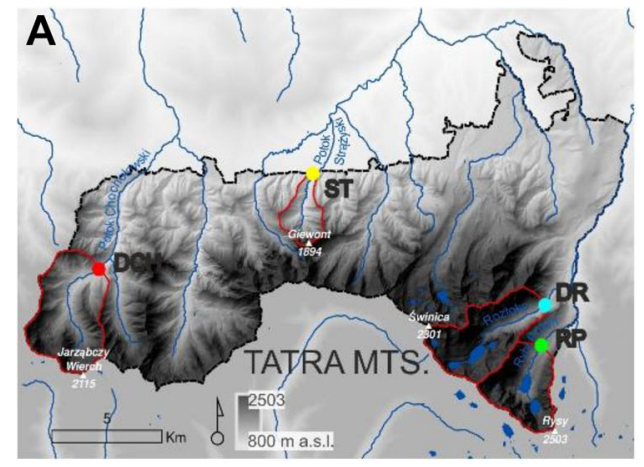

Fig. 4 a The location of four studied water courses: $D C H$ Potok Chochołowski Stream, DR Roztoka Stream, ST Strążyski Potok Stream, RP Rybi Potok Stream. b Peak discharge reconstructions for

not only allowed the patterns of wood accumulations to be reproduced, but also made it possible to test some other features of transport and storage of wood in mountain rivers. High potential for wood transport was indicated in a single-thread reach of the River Czarny Dunajec, of relatively small width. This result was corroborated by a tracking experiment of tagged logs during a flood of 20-year frequency (Wyżga et al. 2016b).

From a viewpoint of flood risk, wood has potential to considerably enlarge the adverse flood impacts, especially in vulnerable sections such as bridges. The bridge at Długopole on the River Czarny Dunajec is considerably threatened by clogging with wood. This may cause flood

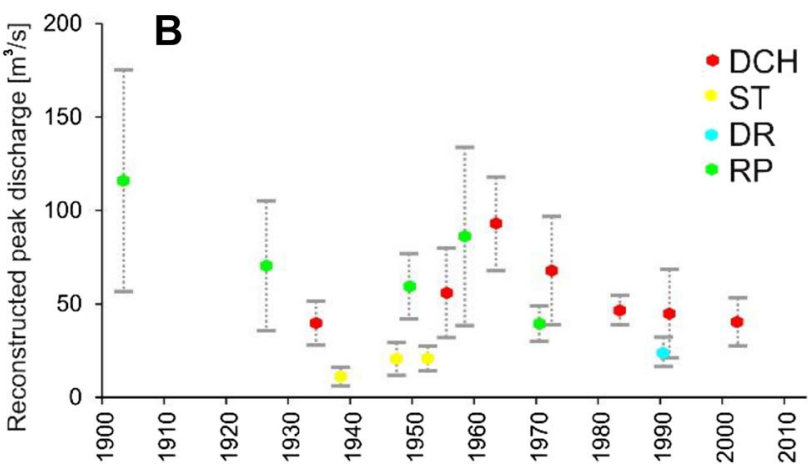

specific event based on scar heights and water levels modelled for individual stream reach and each reconstructed event

damage to adjacent settlements (Ruiz-Villanueva et al. 2016e).

There are very few studies including mobilization of woody material in streams in analysis of flood hazard and flood risk. The feasibility to pass large wood was tested in the River Czarny Dunajec, with the help of scenario-based hydrodynamic modeling. This provided insight into the influence of transport and accumulations of large wood on flood hazard and risk. It also enabled evaluation and assessment of possible management tools-prevention and mitigation.

Significant efforts were made towards characterization of climatic changes in future horizons and the estimation of 

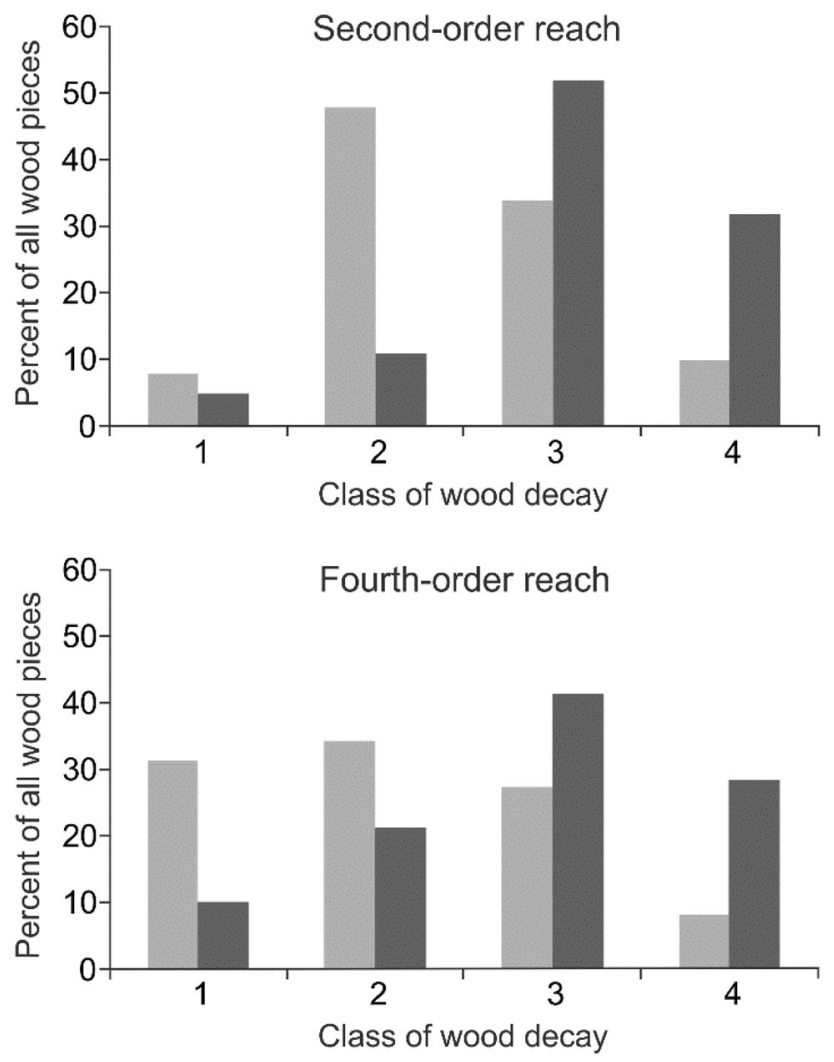

Fig. 5 Comparison of the degree of wood decay determined in two reaches of the Stream Kamienica in 1997 (respectively, a secondorder reach in the upper diagram and a fourth-order reach in the lower diagram), immediately after passage of a large flood (light gray columns) and in 2012, i.e. 15 years after that extreme event (dark gray columns). Classes of wood decay are represented as follows: 1 fresh wood, with bark adhering tightly; 2 loose bark; 3 no bark, hard wood; and 4 no bark, soft wood

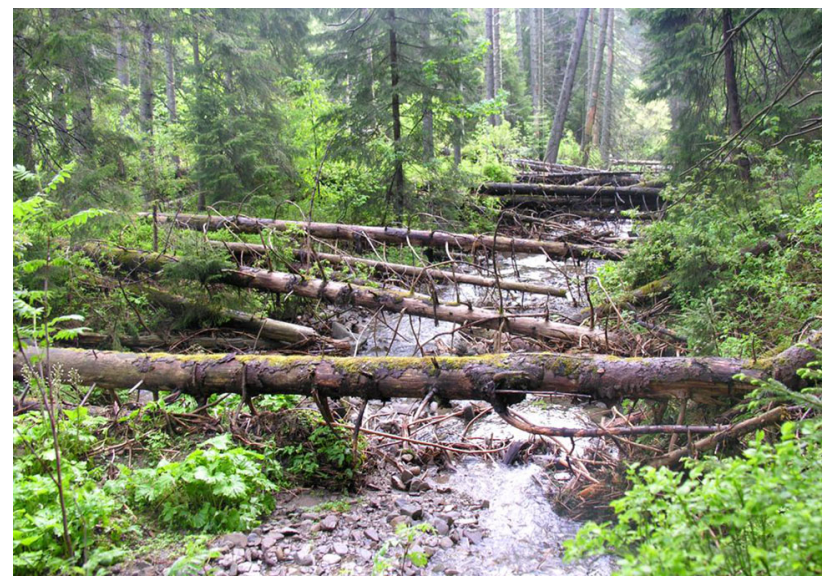

Fig. 6 Small channel width facilitates anchoring of fallen trees on channel banks and small flood discharges in headwater stream reach reduce the potential for mobilization of wood pieces and flood hazard that might result from the transfer of the large wood to lower, inhabited, valley reaches. The photograph shows the Stream Kamienica in the Gorce Mountains National Park

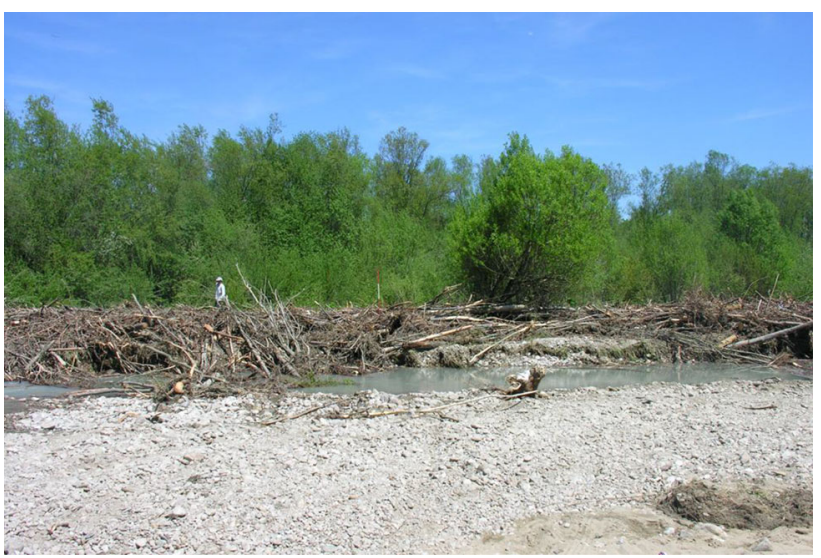

Fig. 7 Large channel width in relation to the length of wood pieces and larger flood discharges facilitating wood flotation result in considerable mobility of wood in mountain rivers. The wood is preferentially retained in wide, unmanaged river reaches (see a large jam in the multi-thread reach of the River Czarny Dunajec), but it can constitute a considerable flood hazard if being accumulated at vulnerable sites such as bridge cross-sections

impact on the size (magnitude), occurrence (frequency), duration as well as spatial spread of projected heavy precipitation and river floods. In the Polish Tatra Mountains, according to different climate models, a warming is expected to result in a seasonal shift and an increase in inter-annual precipitation variability. It is likely to cause an increase in frequency and magnitude of extreme precipitation and severity of flash floods. These findings are of considerable relevance and interest to those responsible for coping with floods in the region (Kundzewicz and Kaczmarek 2000).

\section{Conclusions}

Research objectives and methodology used in the PolishSwiss FLORIST project, a challenging and truly interdisciplinary endeavor, examining flood risk on the northern foothills of the Tatras, were highly innovative. Never before have changes in processes of flood generation in the study area been examined in such a holistic way, accounting analysis of past observation records, carrying out new data collection campaigns, as well as generating future projections.

Our results showed that intense precipitation and river flows in the study area are dominated by considerable interannual as well as inter-decadal variability that indeed heavily influence the direction and magnitude of the identified short-term trends (largely dependent on the years of the beginning and the end of analysis). However, a shift in the seasonality of stream-flow is apparent and, in 
particular, increase in autumn and spring discharges as well as decrease of the magnitude of winter flow.

In the past, dendrogeomorphology had been used worldwide in application to flash flooding; however, the studies carried out during the FLORIST project are likely to be the first regional approach ever to study floods in mountain environment using dendrogeomorphology. The approach to numerical modeling of wood transport, undertaken in this study, is novel and unique, worldwide, and-to the best knowledge of co-authors-no similar work has ever been carried out before.

The information produced in the FLORIST project will undoubtedly have impact on understanding and interpretation of past, present, and future flood risk in the study area. It is expected to help solving practical problems related to regional and local strategies of reduction of flood risk and preparedness to floods. Hence, the generated knowledge, being of considerable scientific interest and importance, is also of vast social and practical relevance.

Acknowledgements This paper reports on results of the Polish-Swiss research project FLORIST (Flood risk on the northern foothills of the Tatra Mountains), financed by a grant (PSPB no. 153/2010) from the Swiss Government through the Swiss Contribution to the enlarged European Union. The FLORIST project was carried out from July 2011 to September 2016. The project consortium consisted of the coordinator - the Institute for Agricultural and Forest Environment of the Polish Academy of Sciences (Poznań, Poland), as well as the project partner institutions: the University of Berne (Berne, Switzerland), and the University of Silesia (Katowice and Sosnowiec, Poland).

Open Access This article is distributed under the terms of the Creative Commons Attribution 4.0 International License (http://crea tivecommons.org/licenses/by/4.0/), which permits unrestricted use, distribution, and reproduction in any medium, provided you give appropriate credit to the original author(s) and the source, provide a link to the Creative Commons license, and indicate if changes were made.

\section{References}

Ballesteros-Cánovas JA, Czajka B, Janecka K, Lempa M, Kaczka RJ, Stoffel M (2015) Flash floods in the Tatra Mountain streams: frequency and triggers. Sci Total Environ 511:639-648

Ballesteros-Cánovas JA, Spyt B, Janecka K, Kaczka RJ, Stoffel M (2016a) Deciphering flood event information from tree-ring data in the Tatra Mountains: implications for hazard assessment. In: Kundzewicz ZW, Stoffel M, Niedźwiedź T, Wyżga B (eds) Flood risk in the Upper Vistula Basin. GeoPlanet: Earth and Planetary Sciences. Springer, Berlin, pp 257-277. ISBN 978-3319-41922-0

Ballesteros-Cánovas JA, Stoffel M, Spyt B, Janecka K, Kaczka RJ, Lempa M (2016b) Paleoflood discharge reconstruction in Tatra Mountain streams. Geomorphology 272:92-101

Kaczka RJ, Spyt B, Janecka K, Niedźwiedź T, Bednarz Z (2016) Climate reconstruction from tree-rings in the Tatra Mountains. In: Kundzewicz ZW, Stoffel M, Niedźwiedź T, Wyżga B (eds) Flood risk in the Upper Vistula Basin. GeoPlanet: Earth and planetary sciences. Springer, Berlin, pp 209-229. ISBN 978-3319-41922-0

Konieczny R, Kundzewicz ZW, Matczak P (2016) Flood risk reduction-opportunities for learning. In: Kundzewicz ZW, Stoffel M, Niedźwiedź T, Wyżga B (eds) Flood risk in the Upper Vistula Basin. GeoPlanet: Earth and planetary sciences. Springer, Berlin, pp 399-418. ISBN 978-3-319-41922-0

Krasovskaia I, Gottschalk L, Kundzewicz ZW (1999) Dimensionality of Scandinavian river flow regimes. Hydrol Sci J 44(5):705-723

Kundzewicz ZW, Kaczmarek Z (2000) Coping with hydrological extremes. Water Int 25(1):66-75

Kundzewicz ZW, Stoffel M (2016) Anatomy of flood risk. In: Kundzewicz ZW, Stoffel M, Niedźwiedź T, Wyżga B (eds) Flood risk in the Upper Vistula Basin. GeoPlanet: Earth and planetary sciences. Springer, Berlin, pp 39-52. ISBN 978-3-31941922-0

Kundzewicz ZW, Lugeri N, Dankers R, Hirabayashi Y, Döll P, Pińskwar I, Dysarz T, Hochrainer S, Matczak P (2010) Assessing river flood risk and adaptation in Europe-review of projections for the future. Mitig Adapt Strat Global Change 15(7):641-656

Kundzewicz ZW, Dobrowolski A, Lorenc H, Niedźwiedź T, Pińskwar I, Kowalczak P (2012) Floods in Poland. Chapter 17. In: Kundzewicz ZW (ed) Changes in Flood Risk in Europe, Special Publication No. 10. IAHS Press, Wallingford, pp 319-334

Kundzewicz ZW, Pińskwar I, Brakenridge GR (2013) Large floods in Europe, 1985-2009. Hydrol Sci J 58(1):1-7 (Also: Corrigendum, Hydrological Sciences Journal, 58(3), 736-736)

Kundzewicz ZW, Kanae S, Seneviratne SI, Handmer J, Nicholls N, Peduzzi P, Mechler R, Bouwer LM, Arnell N, Mach K, MuirWood R, Brakenridge GR, Kron W, Benito G, Honda Y, Takahashi K, Sherstyukov B (2014a) Flood risk and climate change: global and regional perspectives. Hydrol Sci J 59(1):1-28

Kundzewicz ZW, Stoffel M, Kaczka RJ, Wyżga B, Niedźwiedź T, Pińskwar I, Ruiz-Villanueva V, Łupikasza E, Czajka B, Ballesteros-Canovas JA, Małarzewski Ł, Choryński A, Janecka K, Mikuś P (2014b) Floods at the northern foothills of the Tatra Mountains-a Polish-Swiss research project. Acta Geophys 62:620-641

Kundzewicz ZW, Stoffel M, Niedźwiedź T, Wyżga B (eds) (2016) Flood risk in the Upper Vistula Basin. GeoPlanet: Earth and planetary sciences. Springer, Berlin. ISBN 978-3-319-41922-0

Kundzewicz ZW, Krysanova V, Dankers R, Hirabayashi Y, Kanae S, Hattermann FF, Huang S, Milly PCD, Stoffel M, Driessen PPJ, Matczak P, Quevauviller P, Schellnhuber H-J (2017) Differences in flood hazard projections in Europe-their causes and consequences for decision making. Hydrol Sci J 62(1):1-14

Łupikasza E, Niedźwiedź T, Pińskwar I, Ruiz-Villanueva V, Kundzewicz ZW (2016) Observed changes in temperature and precipitation and relationship between them, in the Upper Vistula Basin. In: Kundzewicz ZW, Stoffel M, Niedźwiedź T, Wyżga B (eds) Flood risk in the Upper Vistula Basin. GeoPlanet: Earth and planetary sciences. Springer, Berlin, pp 155-187. ISBN 978-3-319-41922-0

Matczak P, Lewandowski J, Choryński A, Szwed M, Kundzewicz ZW (2016) Stability and change of Floyd risk governance in Poland. In: Kundzewicz ZW, Stoffel M, Niedźwiedź T, Wyżga B (eds) Flood risk in the Upper Vistula Basin. GeoPlanet: Earth and planetary sciences. Springer, Berlin, pp 381-398. ISBN 978-3-319-41922-0

Mikuś P, Wyżga B, Ruiz-Villanueva V, Zawiejska J, Kaczka RJ, Stoffel M (2016a) Methods to assess large wood dynamics and the associated flood hazard in Polish Carpathian watercourses of different size. In: Kundzewicz ZW, Stoffel M, Niedźwiedź T, Wyżga B (eds) Flood risk in the Upper Vistula Basin. GeoPlanet: 
Earth and planetary sciences. Springer, Berlin, pp 77-101. ISBN 978-3-319-41922-0

Mikuś P, Wyżga B, Radecki-Pawlik A, Zawiejska J, Amirowicz A, Oglęcki P (2016b) Environment-friendly reduction of flood risk and infrastructure damage in a mountain river: case study of the Czarny Dunajec. Geomorphology 272:43-54

Nachlik E, Kundzewicz ZW (2016) History of foods on the Upper Vistula. In: Kundzewicz ZW, Stoffel M, Niedźwiedź T, Wyżga B (eds) Flood risk in the Upper Vistula Basin. GeoPlanet: Earth and Planetary Sciences. Springer, Berlin, pp 279-292. ISBN 978-3-319-41922-0

Niedźwiedź T, Łupikasza E (2016) Change in atmospheric circulation patterns. In: Kundzewicz ZW, Stoffel M, Niedźwiedź T, Wyżga B (eds) Flood risk in the Upper Vistula Basin. GeoPlanet: Earth and planetary sciences. Springer, Berlin, pp 189-208. ISBN 978-3-319-41922-0

Niedźwiedź T, Łupikasza E, Pińskwar I, Kundzewicz ZW, Stoffel M, Małarzewski $Ł$ (2015) Variability of high rainfalls and related synoptic situations causing heavy floods at the northern foothills of the Tatra Mountains. Theoret Appl Climatol 119(1):273-284

Piniewski M, Szczęśniak M, Mezghani A, Kundzewicz ZW (2016) Hydroclimatic projections for the Upper Vistula Basin. In: Kundzewicz ZW, Stoffel M, Niedźwiedź T, Wyżga B (eds) Flood risk in the Upper Vistula Basin. GeoPlanet: Earth and planetary sciences. Springer, Berlin, pp 331-339. ISBN 978-3319-41922-0

Pińskwar I, Choryński A, Kundzewicz ZW, Ruiz-Villanueva V (2016) Projections of precipitation in the northern foothills of the Tatra Mountains. In: Kundzewicz ZW, Stoffel M, Niedźwiedź T, Wyżga B (eds) Flood risk in the Upper Vistula Basin. GeoPlanet: Earth and planetary sciences. Springer, Berlin, pp 311-329. ISBN 978-3-319-41922-0

Radecki-Pawlik A, Wyżga B, Czech W, Mikuś P, Zawiejska J, RuizVillanueva V (2016) Modelling hydraulic parameters of flood flows for a Polish Carpathian river subjected to variable human impacts. In: Kundzewicz ZW, Stoffel M, Niedźwiedź T, Wyżga B (eds) Flood risk in the Upper Vistula Basin. GeoPlanet: Earth and planetary sciences. Springer, Berlin, pp 127-151. ISBN 978-3-319-41922-0

Romanowicz R, Kundzewicz ZW, Meresa HK, Stoffel M, Krysanova V, Doroszkiewicz J (2016) Projections of changes in flood hazard in two headwater catchments of the Vistula in the context of European-scale studies. In: Kundzewicz ZW, Stoffel M, Niedźwiedź T, Wyżga B (eds) Flood risk in the Upper Vistula Basin. GeoPlanet: Earth and planetary sciences. Springer, Berlin, pp 341-359. ISBN 978-3-319-41922-0

Ruiz-Villanueva V, Stoffel M, Wyżga B, Kundzewicz ZW, Czajka B, Niedźwiedź $T$ (2016a) Decadal variability of floods in the northern foreland of the Tatra Mountains. Reg Environ Change 16(3):603-615

Ruiz-Villanueva V, Wyżga B, Hajdukiewicz H, Stoffel M (2016b) Exploring large wood retention and deposition in contrasting river morphologies linking numerical modelling and field observations. Earth Surf Process Landf 41(4):446-459

Ruiz-Villanueva V, Wyżga $B$, Kundzewicz ZW, Niedźwiedź T, Łupikasza E, Stoffel M (2016c) Variability of flood frequency and magnitude during the late 20th and early 21 st centuries in the northern foreland of the Tatra Mountains. In: Kundzewicz ZW, Stoffel M, Niedźwiedź T, Wyżga B (eds) Flood risk in the Upper Vistula Basin. GeoPlanet: Earth and planetary sciences. Springer, Berlin, pp 231-256. ISBN 978-3-319-41922-0

Ruiz-Villanueva V, Wyżga B, Mikuś P, Hajdukiewicz H, Stoffel M (2016d) The role of flood hydrograph in the remobilization of large wood in a wide mountain river. J Hydrol 541(A):330-343

Ruiz-Villanueva V, Wyżga B, Mikuś P, Hajdukiewicz M, Stoffel M (2016e) Potential wood-related hazards at bridges: the Długopole bridge on the Czarny Dunajec River, Polish Carpathians. In: Koboltschnig G (ed) 13th Congress interpraevent 2016, Lucerne, Switzerland, pp 610-618

Ruiz-Villanueva V, Wyżga B, Zawiejska J, Hajdukiewicz M, Stoffel M (2016f) Factors controlling large-wood transport in a mountain river. Geomorphology 272:21-31

Ruiz-Villanueva V, Wyżga B, Zawiejska J, Mikuś P, Hajdukiewicz H, Hajdukiewicz M, Stoffel M (2016g) Large wood transport, deposition and remobilization during floods in the Czarny Dunajec River: outcomes from numerical modelling. In: Kundzewicz ZW, Stoffel M, Niedźwiedź T, Wyżga B (eds) Flood risk in the Upper Vistula Basin. GeoPlanet: Earth and planetary sciences. Springer, Berlin, pp 103-125. ISBN 978-3319-41922-0

Ruiz-Villanueva V, Wyżga B, Mikuś P, Hajdukiewicz M, Stoffel M (2016h) Large wood clogging during floods in a gravel-bed river: the Długopole bridge in the Czarny Dunajec River, Poland. Earth Surf Proc Land 42:516-530. doi:10.1002/esp.4091

Stoffel M, Wyżga B, Marston RA (2016a) Floods in mountain environments: a synthesis. Geomorphology 272:1-9

Stoffel M, Wyżga B, Niedźwiedź T, Ruiz-Villanueva V, BallesterosCánovas JA, Kundzewicz ZW (2016b) Floods in mountain basins. In: Kundzewicz ZW, Stoffel M, Niedźwiedź T, Wyżga B (eds) Flood risk in the Upper Vistula Basin. GeoPlanet: Earth and planetary sciences. Springer, Berlin, pp 23-37. ISBN 978-3319-41922-0

Wyżga B, Zawiejska J, Mikuś P, Kaczka RJ (2015) Contrasting patterns of wood storage in mountain watercourses narrower and wider than the height of riparian trees. Geomorphology 228:275-285

Wyżga B, Kundzewicz ZW, Ruiz-Villanueva V, Zawiejska J (2016a) Flood generation mechanisms and changes in principal drivers. In: Kundzewicz ZW, Stoffel M, Niedźwiedź T, Wyżga B (eds) Flood risk in the Upper Vistula Basin. GeoPlanet: Earth and planetary sciences. Springer, Berlin, pp 55-75. ISBN 978-3-31941922-0

Wyżga B, Mikuś P, Zawiejska J, Ruiz-Villanueva V, Kaczka RJ, Czech W (2016b) Log transport and deposition in incised, channelized, and multithread reaches of a wide mountain river: tracking experiment during a 20-year flood. Geomorphology. doi:10.1016/j.geomorph.2016.09.019

Wyżga B, Radecki-Pawlik A, Zawiejska J (2016c) Flood risk management in the Upper Vistula Basin in perspective: traditional versus alternative measures. In: Kundzewicz ZW, Stoffel M, Niedźwiedź T, Wyżga B (eds) Flood risk in the Upper Vistula Basin. GeoPlanet: Earth and planetary sciences. Springer, Berlin, pp 361-380. ISBN 978-3-319-41922-0 